\title{
Movement of bymoviruses and functions of RNA2- encoded proteins of barley yellow mosaic virus
}

\author{
P Schenk 1, A Sohn 1, MJ Adams 2, JF Antoniw 2, J Hamacher ${ }^{3}$, HH Steinbiß 1* \\ 1 Max-Planck-Institut für Züchtungsforschung, Carl-von-Linné-Weg 10, D-50829 Cologne, Germany; \\ 2 Plant Pathology Department, Institute of Arable Crops Research-Rothamsted, Harpenden, Herts AL5 2JQ, UK; \\ 3 Institut für Pflanzenkrankheiten, Nußallee 9, D-53115 Bonn, Germany
}

(Received 20 May 1995; accepted 4 July 1995)

\begin{abstract}
Summary - Observations and experimental data that were obtained from plants infected with bymoviruses such as barley yellow mosaic virus (BaYMV), barley mild mosaic virus (BaMMV), or wheat spindle streak mosaic virus (WSSMV) suggested that long-distance transport follows the phloem pathway. Inoculation of barley roots with BaMMV via viruliferous zoospores of Polymyxa graminis and mechanical inoculation of leaves revealed that viral transport from shoots to roots occurs in less than $5 \mathrm{~d}$ while movement from roots to shoots could only be detected after 5-6 weeks. A model for long-distance transport of bymoviruses was developed which shows that the bymovirus infection cycle passes through 4 main stages. During these stages an up- and downward movement may be important for sufficient replication and successful transmission of bymoviruses. The $28 \mathrm{kDa}$ protein of BaYMV (RNA2) may have a function in either movement or replication as it was often found associated with virus particles. The other RNA2-encoded protein of BaYMV, a $70 \mathrm{kDa}$ protein, could be involved in fungal transmission.
\end{abstract}

bymovirus / virus movement / barley yellow mosaic virus / barley mild mosaic virus / wheat spindle streak mosaic virus / Polymyxa graminis

Résumé - Étude de la migration des bymovirus et fonctions possibles des protéines de transport codées par I'ARN2 du virus de la mosaïque jaune de l'orge. Les diverses observations réalisées et les données expérimentales obtenues à partir de plantes infectées par les bymoviruses, tel que le virus de la mosaïque jaune de l'orge (BaYMV), le virus de la mosaïque modérée de l'orge (BaMMV) ou le virus de la mosaïque striée en fuseaux du blé (WSSMV) suggèrent que leur transport à longue distance utilise les vaisseaux du phloème. L'inoculation des racines d'orge par le BaMMV, avec des zoospores de Polymyxa graminis contaminés par le virus, et linoculation mécanique de feuilles révèlent que le transport du virus des feuilles aux racines s'effectue en moins de $5 \mathrm{j}$, tandis que le mouvement inverse est détecté 5 à 6 sem après l'infection. Nous avons développé un modèle d'étude du transport à longue distance du bymovirus montrant que le cycle infectieux comprend 4 étapes principales. Le transport ascendant ou descendant des bymovirus pourrait jouer un rôle important pour leur réplication et leur transmission. La protéine de $28 \mathrm{kDa}$ du BaYMV (ARN2) pourrait intervenir dans le transport ou la réplication du virus, car elle est souvent trouvée associée aux particules virales. L'ARN2 codant pour une seconde protéine de BaYMV de $70 \mathrm{kDa}$ pourrait participer à la capacité vectrice du champignon virulifère.

bymovirus / mouvement viral / virus de la mosaïque jaune de l'orge / virus de la mosaïque modérée de l'orge / virus de la mosaïque striée en fuseaux du blé / Polymyxa graminis

* Correspondence and reprints 
In recent years bymoviruses, such as barley yellow mosaic virus (BaYMV), barley mild mosaic virus (BaMMV) or wheat spindle streak mosaic virus (WSSMV), have become the causal agents of economically important diseases with yield losses of $30-70 \%$ (Slykhuis, 1970; Huth, 1981; Miller et al, 1991, 1992). Symptoms consist of yellow spots and stripes on the leaves and several inclusion types in infected cells, such as crystal-like cytoplasmic inclusions ( $\mathrm{CCl}$ ) and 'pinwheel'-structures $(\mathrm{Cl})$ that are typically found for potyviruses (Huth et al, 1984; Schenk et al, 1993). However, in contrast to potyviruses, bymoviruses are transmitted by the soil-borne fungus Polymyxa graminis. Their genome is bipartite (RNA1 and RNA2) and consists of 2 positive-sense single-stranded RNAs.

In order to better understand the processes that cause damage to infected plants we investigated the movement of bymoviruses. Symptom development of plants grown in fields or in the greenhouse, such as winter barley infected with BaYMV or BaMMV or wheat infected with WSSMV, indicated that all bymoviruses are likely to share a common transport mechanism. Usually the first symptoms appear on the lower part of the youngest leaf, and during plant growth all new leaves become infected. After stem extension begins new leaves are free of symptoms. Western blot analyses with antisera against viral proteins, such as the capsid protein, showed that the appearance of symptoms correlated with the detection of viruses. Electron microscopy studies of BaYMV or WSSMVinfected tissues revealed that most of the infected cells were situated in and around vascular bundles (Schenk et al, 1993). In areas of yellow stripes on the leaves chloroplasts were severely damaged and showed signs of membrane degradation (fig 1). In some cases elongated structures were found to be associated with plasmodesmata between infected cells and their neighbouring, as yet uninfected, cells. These structures may be involved in viral cell-to-cell movement. In studies of viral movement after inoculation, leaves of barley plants were mechanically inoculated with BaMMV and roots were inoculated using viruliferous zoospores of $P$ graminis. Following inoculation with zoospores, virus could be detected in roots after 1 week using Western blot analyses with capsid protein or reverse transcriptase-PCR (RT-PCR; Schenk et al, 1995). Virus moved to leaves in 5-6 weeks, but plants usually had to be cut to stimulate virus movement. Following mechanical inoculation, virus could be detected in leaves of a susceptible cultivar within $3 \mathrm{~d}$.
Western blot analyses and RT-PCR showed that virus was present in the roots by $5 \mathrm{~d}$. BaMMV was not detected by any method in the leaves or roots of a resistant cultivar, indicating that the virus did not multiply in it. When leaves were mechanically inoculated on a small area of a leaf only, BaMMV capsid protein was detected below the inoculated site at $4 \mathrm{~d}$ and in young growing leaves and roots at $13 \mathrm{~d}$ after inoculation but never above the inoculation site or in older leaves. For comparison, plants were provided with ${ }^{14} \mathrm{CO}_{2}$ at a small area of a leaf, and subsequently samples were taken at different times after inoculation (5, 10,30 and $60 \mathrm{~min})$. Similar to viral movement after inoculation of a small area of a leaf, ${ }^{14} \mathrm{C}$-labelled assimilates mainly moved to the roots but much faster $(30 \mathrm{~cm} / \mathrm{h})$ than viruses could be detected. These data suggest that bymoviruses use the phloem for long-distance transport like many other plant viruses (Matthews, 1991; Leisner and Turgeon, 1993). Figure 2 shows a model of the bymovirus infection cycle which undergoes 4 main stages during which up- and downward movement may contribute to a higher virus titer in $P$ graminis. According to this hypothetical model the following processes may take place.

After infection with viruliferous zoospores viruses replicate in the root cells and spread from cell to cell until the phloem tissue is reached. At times of a temporary reversal of the principal phloem flux (eg, cold damage or cutting of leaves) viruses move to the leaf apex. When new leaves start growing, viruses move up, replicate and spread from cell to cell in and around vascular bundles. Symptoms (yellow stripes) occur due to cell damage and chloroplast degeneration. During this time newly formed virus particles follow the phloem pathway and are transported within days mainly to new growing leaves and to the roots where new viruliferous resting spores are formed. Typically this process continues for several months and may contribute to a high virus titer in resting spores of $P$ graminis. At the same time there is also multiplication and transmission of viruses to a lower extent in the roots. However, these processes become more difficult when plants continue to grow and particularly when the apex moves up during stem extension. At that stage plant growth may be too fast and distances may be too long for viruses to move to the apex. Finally all new leaves are free of symptoms allowing plants to recover to some extent. Therefore yield losses depend very much on the climatic conditions.

The presence of 2 RNAs in the bymovirus genome gave rise to the question of which func- 
tion of RNA2 makes it essential for the bymovirus disease cycle. Functions of RNA2-encoded proteins of BaYMV were investigated by using the corresponding antibodies. Both the $28 \mathrm{kDa}$ and the $70 \mathrm{kDa}$ protein, were localized in crystal-like cytoplasmic inclusion bodies, the most dominant structures of infected barley cells (Schenk et al, 1993). Immunoprecipitation, Western blot analysis and electron microscopy of isolated BaYMV particles indicated that the $28 \mathrm{kDa}$ protein is often

Fig 1. Electron microscopy of chloroplasts in cells of healthy (A) and WSSMV-infected wheat leaves (B) Plants originate from southern France and were provided by Prof Signoret (UFR de biologie et pathologie végétale, ENSA,
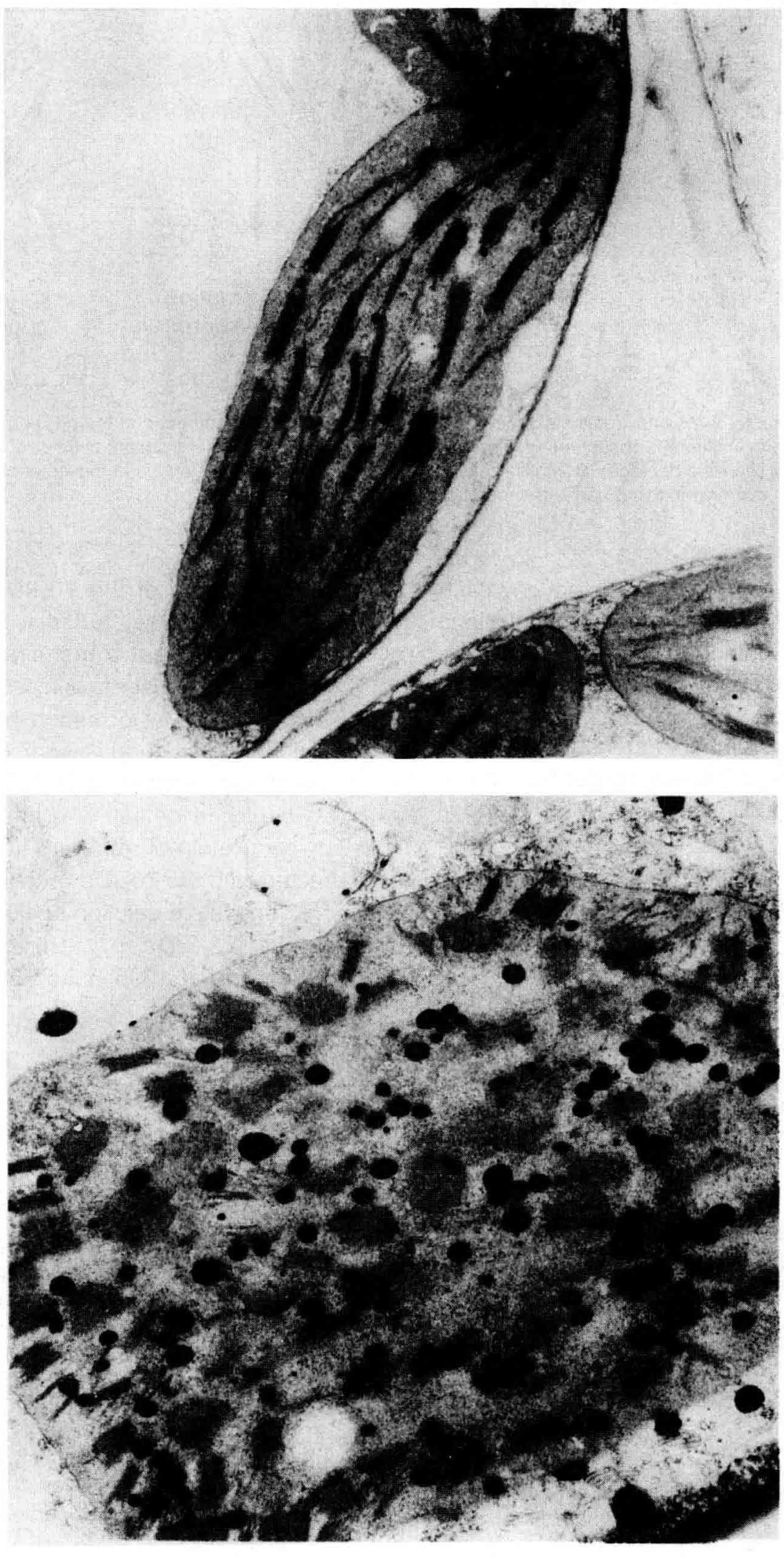
Montpellier). 


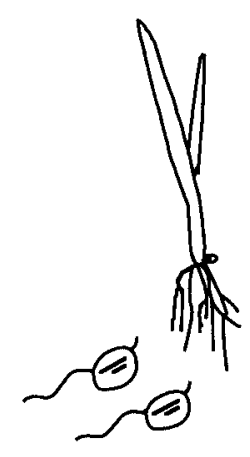

zoospores

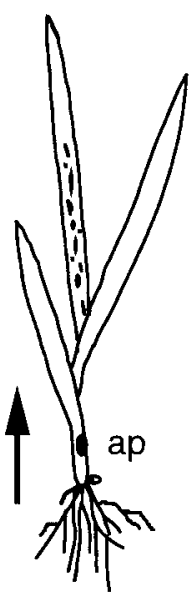

B

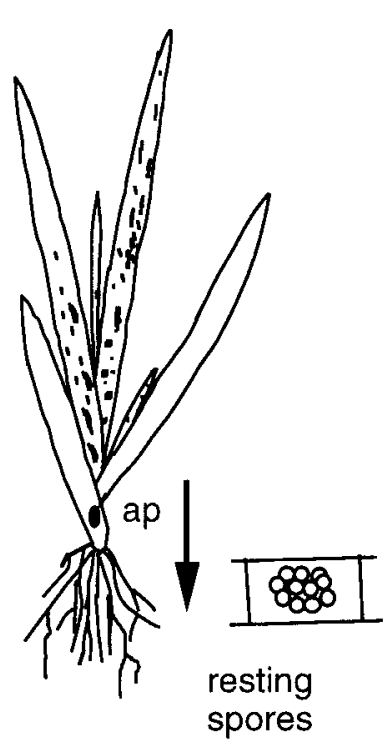

C

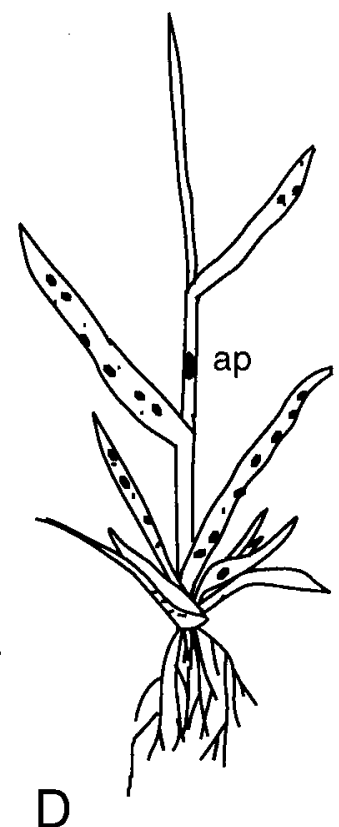

Fig 2. Hypothetical model for the bymovirus infection cycle. Note the symptom development and the position of the apex (ap) during all stages. A: Infection with viruliferous zoospores of $P$ graminis; B: movement from roots to shoots at times of a temporary reversal of the principal phloem flux (eg, cold damage); $\mathrm{C}$ : multiplication of bymoviruses mainly in leaves and movement from shoots to roots via the phloem pathway. D: 'overgrowing' and partial regeneration of the plants.

associated with virus particles but is not covalently linked to them. It may play an important role in processes where binding to virus particles is necessary, such as replication or movement. In addition to that, the $28 \mathrm{kDa}$ protein shows some sequence homologies in motif areas to the helper component protease of some potyviruses. In vitro translational studies (Davidson et al, 1991) and in vivo expression of the full cDNA clone of BaYMVRNA2 in Escherichia coli revealed that the $28 \mathrm{kDa}$ protein is a protease that autocatalytically cleaves from the encoded $98 \mathrm{kDa}$ polyprotein.

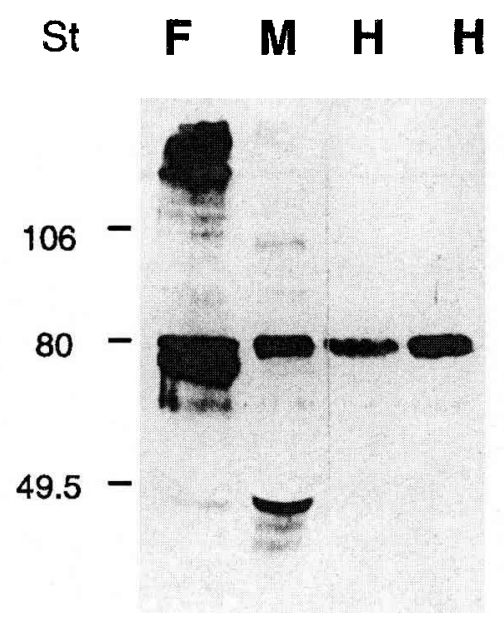

Fig 3. Western blot analysis of leaf extracts from BaYMVinfected plants. F: From the field; $\mathbf{M}$ : from the greenhouse after 7 mechanical passages; $\boldsymbol{H}$ : leaf extracts from healthy plants.
The function of the $70 \mathrm{kDa}$ protein is still a matter of debate, but it is suspected to be involved in fungal transmission. After several mechanical passages with the Japanese isolate BaYMV-I1 (To1), provided by Dr Kashiwasaki (National Agricultural Research Centre, Tsukuba, Japan; Kashiwasaki et al, 1989), no $70 \mathrm{kDa}$ protein could be detected in infected plants, but a smaller protein of about $45 \mathrm{kDa}$ appeared which reacted with the $70 \mathrm{kDa}$ protein antibodies (fig 3). This suggests a deletion analogous to that shown for the $73 \mathrm{kDa}$ protein of BaMMV-RNA2 (Dessens et al, 1995; Jacobi et al, 1995).

\section{REFERENCES}

Davidson AD, Pröls M, Schell J, Steinbiß HH (1991) The nucleotide sequence of RNA 2 of barley yellow mosaic virus. J Gen Virol 72, 989-993

Dessens JT, Nguyen M, Meyer M (1995) Primary structure and sequence analysis of RNA2 of a mechanically transmitted barley mild mosaic virus isolate: an evolutionary relationship between bymoand furoviruses. Arch Virol 140, 325-333

Huth W (1981) Das Gelbmosaikvirus der Gerste. BASF-Mitteil, Landbau BASF Agric Bull 4

Huth W, Lesemann DE, Paul HL (1984) Barley yellow mosaic virus: purification, electron microscopy, serology, and other properties of two types of the virus. Phytopathol Z 111, 37-54 
Jacobi V, Peerenboom E, Schenk PM, Antoniw JF, SteinbiB HH, Adams MJ (1995) Cloning and sequence analysis of RNA 2 of a mechanically transmitted UK isolate of barley mild mosaic bymovirus (BaMMV). Virus Res 37, 99-111

Kashiwasaki S, Ogawa K, Usugi T, Omura T, Tsuchizaki T (1989) Characterization of several strains of barley yellow mosaic virus. Ann Phytopath Soc Jpn 55, 16-25

Leisner SM, Turgeon R (1993) Movement of virus and photoassimilate in the phloem: a comparative analysis. Bioassays 15, 741-748

Matthews REF (1991) Plant Virology. 3rd edition, Academic Press, San Diego, CA, USA

Miller NR, Bergstrom GC, Gray SM (1991) Identity, prevalence, and distribution of viral diseases of win- ter wheat in New York 1988 and 1989. Plant Dis 75, 1105-1109

Miller NR, Bergstrom GC, Sorrels ME (1992) Effect of wheat spindle streak mosaic virus on winter wheat in New York. Phytopathology 82, 852-857

Schenk PM, Steinbiß HH, Müller B, Schmitz K (1993) Association of two barley yellow mosaic virus (RNA2) encoded proteins with cytoplasmic inclusion bodies revealed by immunogold localization. Protoplasma 173, 113-122

Schenk P, Antoniw JF, Batista MF, Jacobi V, Adams MJ, Steinbiß HH (1955) Movement of barley mild mosaic and barley yellow mosaic viruses in leaves and roots of barley. Ann Applied Biol 126 (in press)

Slykhuis JT (1970) Factors determining the development of wheat spindle streak mosaic virus caused by a soilborne virus in Ontario. Phytopathology 60, 319-331 